\title{
VERIFICATION OF THE THERMAL EXPANSION EFFECT OF SILICONE MOLDS INTENDED FOR PRODUCTION OF THE PROTOTYPE COMPONENTS USING VACUUM CASTING TECHNOLOGY
}

\author{
Peter Spišák ${ }^{1, *}$, Róbert Sásik ${ }^{1}$, Ján Steininger ${ }^{1}, J_{0 z e f ~ J e n i s}{ }^{2}$ \\ ${ }^{1}$ Institute of Competitiveness and Innovations, University of Zilina, Zilina, Slovak Republic \\ ${ }^{2}$ Department of Design and Mechanical Elements, Faculty of Mechanical Engineering, University of Zilina, Zilina, \\ Slovak Republic \\ *E-mail of corresponding author: peter.spisak@fstroj.uniza.sk
}

\section{Resume}

The article deals with vacuum casting technology and especially with the assessment of the influence of the tempering temperature of silicone molds on the dimensions of future castings. The aim was to evaluate the actual size of the castings, using different tempering temperatures of the molds and different casting materials. After examining the resulting dimensions of the individual castings, a procedure was established by which these effects could be minimized. In the end, a test of the proposed procedure is performed, which confirmed its correctness.

\section{Article info}

Received 14 June 2021

Accepted 12 September 2021

Online 23 November 2021

\section{Keywords:}

tempering,

vacuum casting,

thermal expansion, silicone mold

\section{Introduction}

The high demand for the new products at the market forces manufacturers to constantly improve and accelerate their production process. Everyone tries to shorten the time from product development to its launch, as much as possible. Rapid response to changes in demand is one of the most important factors of competitiveness. With this in mind, companies try to involve as many modern technologies as possible in the process prototypes development, including use of simulations and analyses [1-3].

They compete who will develop the best and cheapest product in the shortest time possible. One of the technologies that can significantly reduce the time required for the product development and production is the Rapid Prototyping technology. Its development dates back to 1986 and its practical use was the most widespread after 1996 in the automotive industry and now in development of electric cars, as well, [4-6].

This method utilises the latest knowledge about materials and laser technologies and is able to produce even very complex models in a short period of time. The basis is a process, in which the model is created by gradually adding materials to a computer-controlled machine.
The Vacuum Casting technology is one of the frequently used technologies in component development. The essence of the technology lies in the casting of various types of material (rubber, plastic, wax) in a vacuum into the most common silicone moulds. This technology is the most efficient in small verification batches of $10-20$ pieces, being far more advantageous either in terms of the time required for production or financially compared to conventional methods of production [7].

\section{Vacuum casting}

The method of vacuum casting into silicone moulds is used for production of functional plastic prototypes or wax meltable models. Models used on the 3D printers or $3 \mathrm{D}$ production systems are mainly used as master models.

The main advantages of vacuum casting into a silicone mould include the ability to cast very complex models, thin-walled models, models with a negative bevel, high-precision copying of the master model surface, as well as the low cost of the prototype, compared to the plastic injection. Vacuum casting is one of the Rapid Prototyping technologies, which allows to quickly obtain a functional prototype and thus speed up 


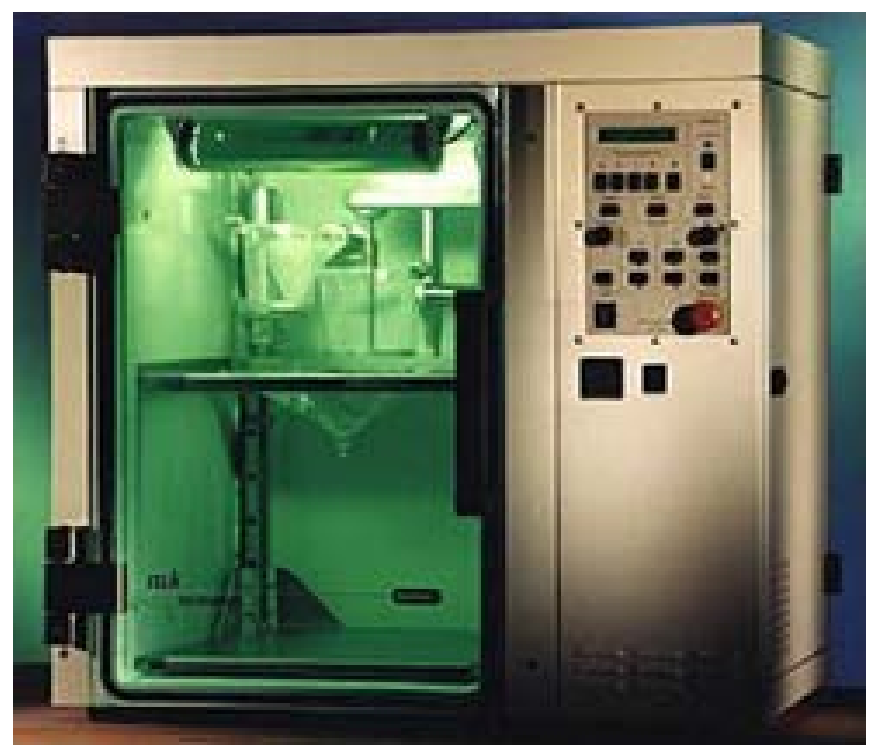

Figure 1 Vacuum chamber MK Technology System 1

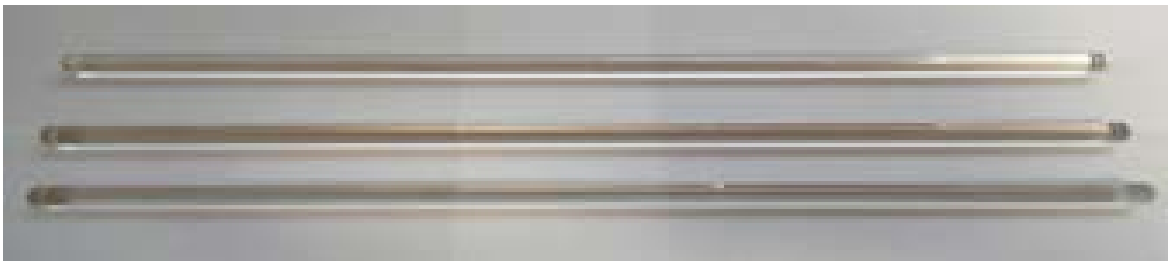

Figure 2 Master model - Glass cylinder

the new product development process. Vacuum casting can also be used to produce the wax models for melt casting [8].

The production of the mould and consequently the components themselves is very fast. For simple shaped parts it is possible to have the first copy made after 5-6 hours, which is much faster than with production in a conventional way (aluminium moulds, injection moulding machine). Vacuum chamber that was used to make the molds and castings is shown in Figure 1.

Materials intended for vacuum casting are the most often two-component polyurethanes with different properties, which allows to achieve properties similar to rubber, polypropylene, ABS plastic, or polycarbonate. If one uses the plastics with good sliding properties, it is also possible to produce complicated components of small dimensions, such as gears [7, 9].

The casting production process can be divided into two main groups:

Production of mould, which includes the following operations:

- preparation of the master model,

- preparation for mould production,

- mould production,

- demoulding of the master model,

- preparation of the mould for the casting process. Casting production:

- preparation of material for casting,

- vacuuming and casting,

- tempering,
- removing the casting from the mould,

- finalisation of the casting.

\section{Verification of the thermal expansion effect of silicone moulds}

From the practical experience with the VC technology, it was observed that there is a certain dimensional instability, especially with larger castings, such as bearing cages or gear prototypes [10-11]. This is due to the thermal expansion of the silicone during the tempering in the furnace (oven/kiln).

SP ICON A40 Protoform silicone was used to make the mold. Its main features are:

- high chemical resistance to plasticizers and aggressive components of some resins,

- high tensile strength, tear resistance, abrasion resistance: guarantees long mold life,

- high accuracy in reproducing small details,

- high dimensional and shape stability,

- high temperature resistance,

- excellent self-separating effect.

The expansion confirmed by the manufacturer at 70 ${ }^{\circ} \mathrm{C}$ is $0.7 \%$.

To verify the thermal expansion, a glass cylinder with a diameter of $13 \mathrm{~mm}$ and a length of $300.05 \mathrm{~mm}$ was used as the master model. Master model is shown in Figure 2.

Then, a silicone mould was produced, into which 


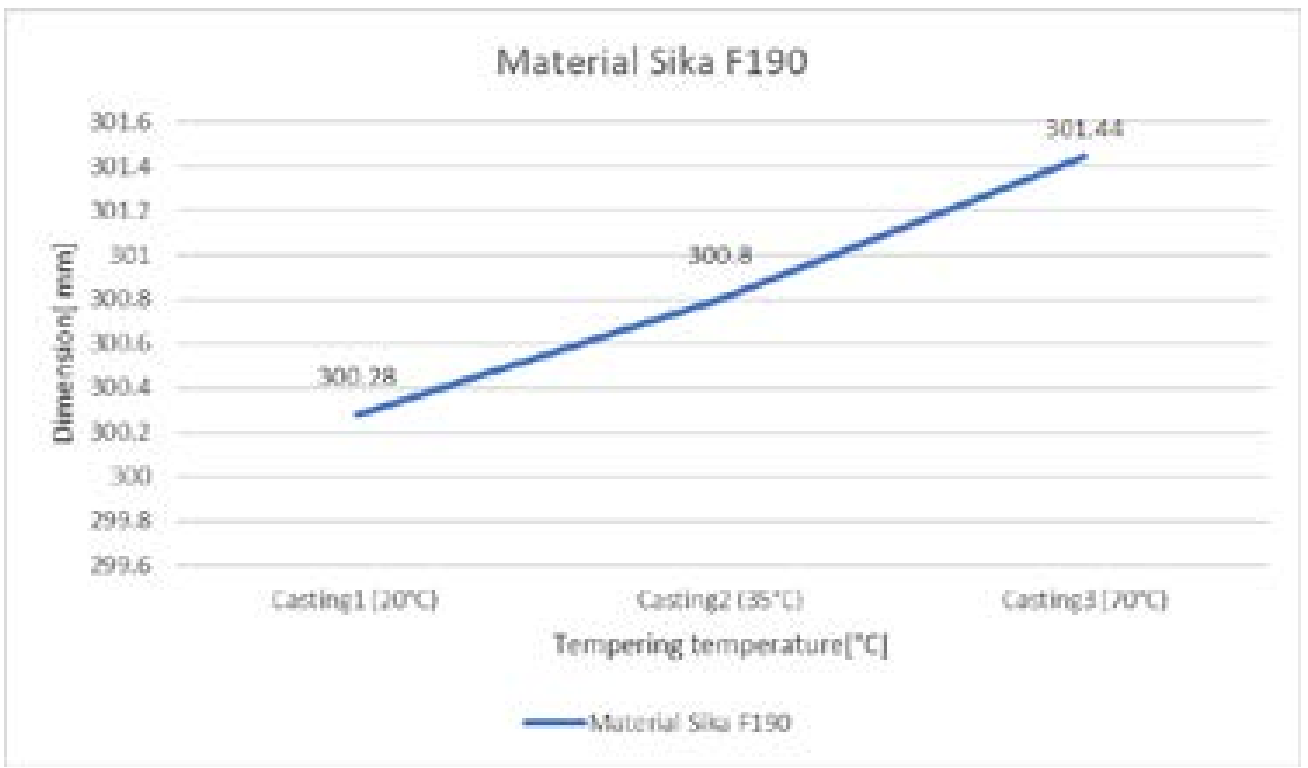

Figure 3 Dependence of thermal expansion on tempering temperature 1

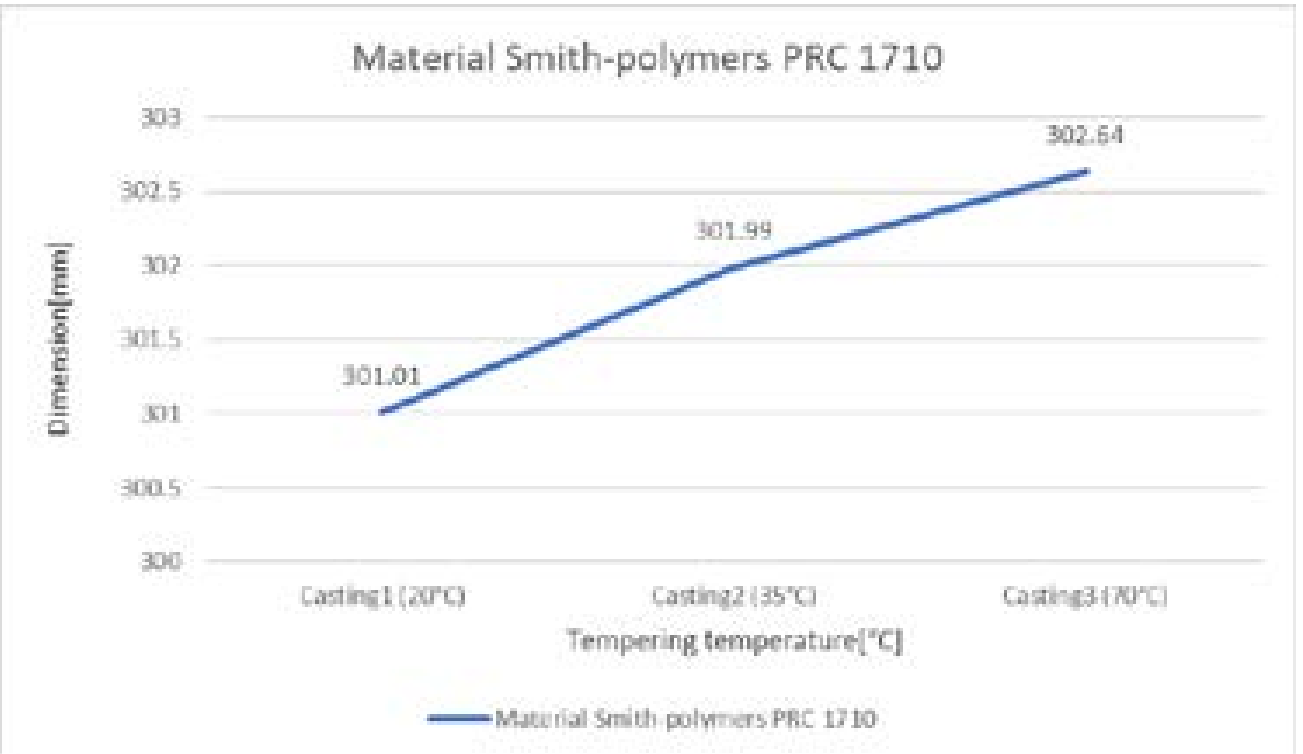

Figure 4 Dependence of thermal expansion on tempering temperature 2

several types of casting materials were then cast at different temperatures. As the number of castings increases, the silicone mold degrades, resulting in deterioration of the surface quality and roughness of the casting. Therefore, it is necessary to produce a new mold after about ten castings. This degradation depends on the following factors: shape and surface quality of the master model, type of casting material used, type of silicone catalyst used, frequency of use of the mold, tempering temperature, [12-13].

- The first casting of each material was cast in a mould tempered to $20^{\circ} \mathrm{C}$.

- A second casting of each material was cast into a mould tempered at $35{ }^{\circ} \mathrm{C}$.

- A third casting of each material was cast in a mould tempered to $70^{\circ} \mathrm{C}$.

\section{$4 \quad$ Material 1 - Sika F190}

The advantage of this material is low viscosity, ease of use, it is especially suitable for larger castings. The final colour of the casting is beige. Dependence of thermal expansion on tempering temperature for material F190 is shown in Figure 3 [14].

\section{Material 2 - Smith - polymers PRC1710}

It is a transparent UV stable material which is mainly used in the automotive industry. Its advantages are the high mechanical properties, UV resistance, high transparency. Dependence of thermal expansion on tempering temperature for material PRC1710 is shown in Figure 4 [15]. 


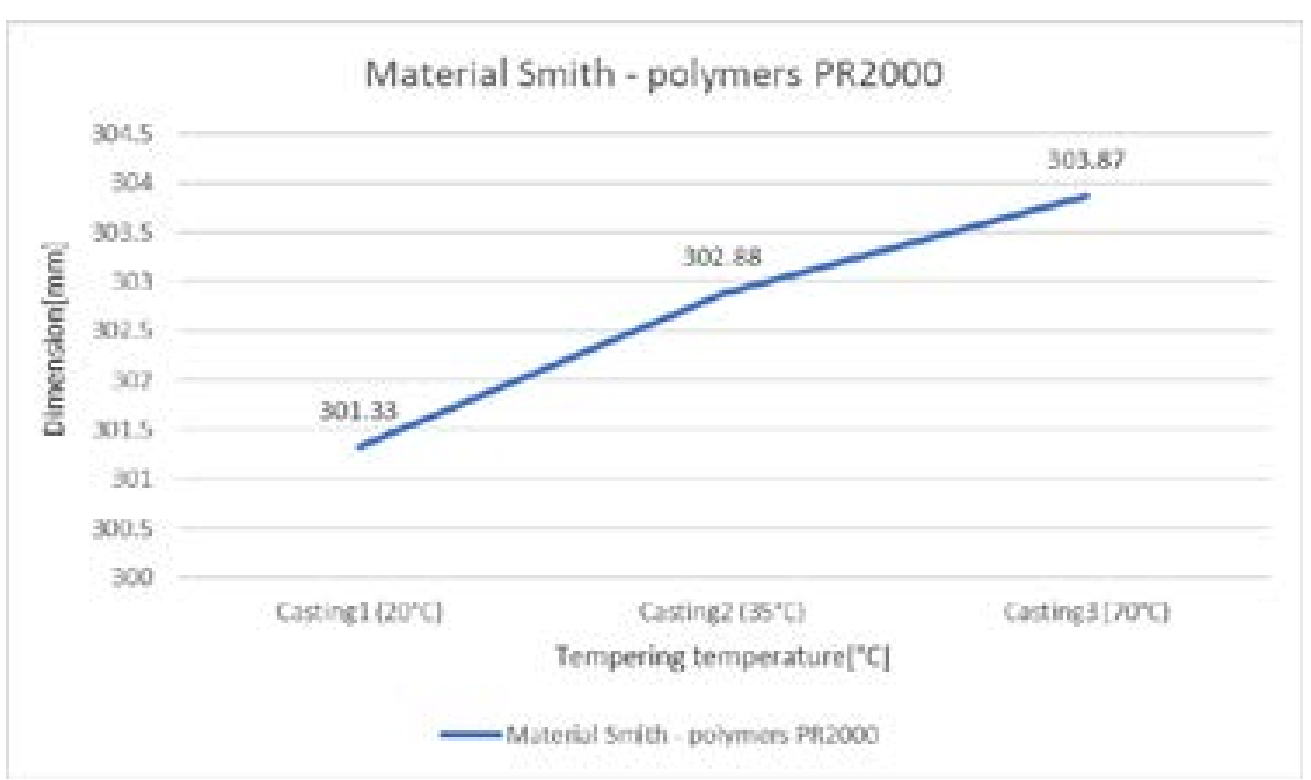

Figure 5 Dependence of thermal expansion on tempering temperature 3

Table 1 Summary of Moulds thermal expansion results

\begin{tabular}{cccc}
\hline Material & F190 & PRC1710 & PR2000 \\
\hline Master model [mm] & 300.05 & 300.05 & 300.05 \\
Casting 1 [mm] & 300.28 & 301.01 & 301.33 \\
Casting 2 [mm] & 300.8 & 301.99 & 302.88 \\
Casting $3[\mathrm{~mm}]$ & 301.44 & 302.64 & 303.87 \\
\hline
\end{tabular}

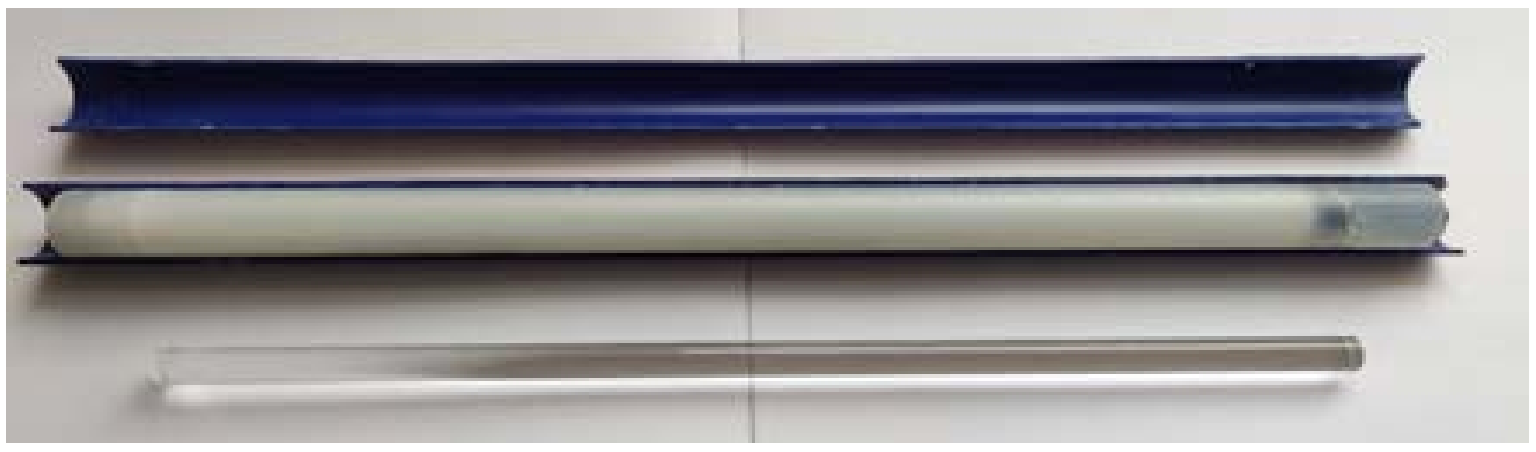

Figure 6 Silicone mould with casting from the PRC1710 material

\section{Material 3 - Smith - polymers PR2000}

The advantage of this material is low viscosity, short demoulding time, high toughness. The resulting colour is white. It is not UV stable. Dependence of thermal expansion on tempering temperature for material PR2000 is shown in Figure 5 [15].

Summary of Moulds thermal expansion results is shown in Table 1.

To verify the correctness of the previous findings, the PR2000 material and the tempering temperature of $70{ }^{\circ} \mathrm{C}$ were chosen, where the length increase was the largest. The original master model had a size of $300.05 \mathrm{~mm}$, the casting had a size of $303.87 \mathrm{~mm}$, which is an increase of $1.27 \%$. Thus, if one wants the resulting casting to have a size of $300.00 \mathrm{~mm}$, one should adjust the master model to $296.19 \mathrm{~mm}$. After modifying the master model to the size of $296.19 \mathrm{~mm}$, a new silicone mould was produced. Subsequently, the mould warmed up to $70{ }^{\circ} \mathrm{C}$ and the mould cavity was filled with PR2000. After the time specified by the manufacturer for tempering the material, the casting was removed and we checked its size. It was $300.03 \mathrm{~mm}$, which confirmed the correctness of the master model modification to minimize the effect of thermal expansion of the silicone mould. Silicone mould and casting from the PRC1710 material is shown in Figure 6.

\section{Conclusion}

The result shows that the thermal expansion of silicone moulds is affected not only by the tempering 
itself, but by the type of casting material used, as well. Due to the fact that the used material was two-component polyurethane resins, when mixed it caused a chemical reaction, which generates additional heat and thus further impacts the extensibility of the mould.

Therefore, when designing the master model, it is necessary to take into account the material from which will the casting be produced and adjust the dimensions accordingly, if possible. (3D printing, milling ...).

\section{Acknowledgment}

This work was supported by Grant System of University of Zilina No. 1/2020 (8085).

\section{References}

[1] TOMASIKOVA, M., TROPP, M., GAJDOSIK, T., KRZYWONOS, L, BRUMERCIK, F. Analysis of transport mechatronic system properties. Procedia Engineering [online]. 2017, 192, p. 881-886. ISSN 1877-7058. Available from: https://doi.org/10.1016/j.proeng.2017.06.152

[2] BRUMERCIK, F., BASTOVANSKY, R., LUKAC, M., GLOWACZ, A. Molybdenum strip test experiments and simulations at various temperatures to determine friction coefficients. Measurement [online]. 2021, 172, 108859. ISSN 0263-2241. Available from: https://doi.org/10.1016/j.measurement.2020.108859

[3] CACO M., KOHAR R., HRCEK S., TRIBULA R., SCERBA P. Use the method of TRIZ in optimizing automated machine for ultrasonic welding. Procedia Engineering [online]. 2017, 192, p. 80-85. ISSN 1877-7058. Available from: https://doi.org/10.1016/j.proeng.2017.06.014

[4] BISTAK, M.; BRUMERCIK, F.; LUKAC, M. Weighing systems in traffic. Scientific journal of Silesian University of Technology - Series Transport [online]. 2017, 97, p. 5 -15. Published: 2017. ISSN 0209-3324, eISSN 2450-1549. Available from: https://doi.org/10.20858/sjsutst.2017.97.1

[5] BISTAK, M., MEDVECKY, S., HRCEK, S. The above-ground weighbridge. Procedia Engineering [online]. 2017, 192, p. 52-57. ISSN 1877-7058. Available from: https://doi.org/10.1016/j.proeng.2017.06.009

[6] MITKA, M., BASTOVANSKY, R., BRUMERCIK, F., IGNACIUK, P. Local resistance of heating molybdenum sheet in a test device. Advances in Science and Technology - Research Journal [online]. 2017, 11(3), p. 87-93. ISSN 2299-8624. Available from: https://doi.org/10.12913/22998624/74182

[7] SPISAK, P., MADAJ, R. The process of preparation prototypes bearing cages for the durability testing. In: 55th International Conference of Machine Design Departments ICMD 2014: proceedings. 2014. ISBN 978-80-0105542-7, p. 271-276.

[8] Wayken rapid manufacturing limited [online] [accessed 2021-05-28]. Available from: https://waykenrm.com/ technologies/ urethane-vacuum-casting/

[9] BRUMERCIK, F., LUKAC, M., CABAN, J., KRZYSIAK, Z., GLOWACZ, A. Comparison of selected parameters of a planetary gearbox with involute and convex-concave teeth. Applied Sciences [online]. 2020, 10(4), 1417. eISSN 2076-3417. Available from: https://doi.org/10.3390/app10041417

[10] MEDVECKY, S., KOHAR, R., HRCEK, S. Dynamic analysis of cage behavior in a tapered roller bearing. In: 7th international Symposium Machine and Industrial Design in Mechanical Engineering KOD $2012=$ Konstruisanje - Oblikovanje - Dizajn: proceedings. 2012. ISBN 978-86-7892- 399-9, p. 45-50.

[11] KUCERA, L., GAJDOSIK, T. The vibrodiagnostics of gears [online]. In: Modern methods of construction design. lecture notes in mechanical engineering. SEVCIK, L., LEPSIK, P., PETRU, M., MASIN, I., MARTONKA, R. (Eds.). Cham: Springer, 2014. ISBN 978-3-319-05202-1, eISBN 978-3-319-05203-8, p. 3118. Available from: https://doi.org/10.1007/978-3-319-05203-8_16

[12] BRUMERCIK, F., BASTOVANSKY, R., LUKAC, M., GLOWACZ, A. Molybdenum strip test experiments and simulations at various temperatures to determine friction coefficients. Measurement [online]. 2021, 172, 108859. ISSN 0263-2241. Available from: https://doi.org/10.1016/j.measurement.2020.108859

[13] DRBUL, M., MARTIKAN, P., BRONCEK, J., LITVAJ, I., SVOBODOVA, J. Analysis of roughness profile on curved surfaces. In: Innovative Technologies in Engineering Production ITEP'18: proceedings [online]. Vol. 244. 2018. Available from: https://doi.org/10.1051/matecconf/201824401024

[14] Modico (in Slovak) [online] [accessed 2021-03-23]. Available from: http://www.modiko.sk/

[15] Smith - Polymers - Smith \& Partner s.r.o. (in Slovak) [online]. Available from: https://www.smith-polymers.com/ polyuretanove-zivice/rapid-prototyping/synthene/ 